University for Business and Technology in Kosovo

UBT Knowledge Center

UBT International Conference

2015 UBT International Conference

Nov 7th, 9:00 AM - 5:00 PM

\title{
Interrelation Community- Academy towards Sustainable Urban Planning
}

Binak Beqaj

University for Business and Technology, bbeqaj@ubt-uni.net

Edmond Hajrizi

University for Business and Technology, ehajrizi@ubt-uni.net

Follow this and additional works at: https://knowledgecenter.ubt-uni.net/conference

Part of the Architecture Commons

\section{Recommended Citation}

Beqaj, Binak and Hajrizi, Edmond, "Interrelation Community- Academy towards Sustainable Urban Planning" (2015). UBT International Conference. 54.

https://knowledgecenter.ubt-uni.net/conference/2015/all-events/54

This Event is brought to you for free and open access by the Publication and Journals at UBT Knowledge Center. It has been accepted for inclusion in UBT International Conference by an authorized administrator of UBT Knowledge Center. For more information, please contact knowledge.center@ubt-uni.net. 


\title{
Interrelation Community- Academy towards Sustainable Urban Planning
}

\author{
Binak Beqaj ${ }^{1}$, Edmond Hajrizi ${ }^{2}$ \\ ${ }^{1,2}$ UBT - Higher Education Institution \\ \{bbeqaj ${ }^{1}$, ehajrizi² $\} @$ ubt-uni.net
}

\begin{abstract}
Considering urban development's World-wide, which are based on economic, social, environmental, cultural trends and good governance; towards sustainable development of urban areas, while there coming y ears will be concentrated most of the World's population, as result of that is very important development of interrelations Community-Academy conversely, in context of promotion of expected results such:

- Academic institutions as community based organization

- Community with base on general development projects

- Determination of common development objectives

- Sustainability through economic, social and environmental dimension

In general the aim of this study is through used comparative research methods and literature review, to present a better picture from relevant facts and concepts to possible benefits from developments in relation Community-Academy, as very important component of new approach to urban development
\end{abstract}

Keywords: urban, economic, social, academy

\section{Introduction}

Planning process is complex and should be based on relationships between different planning frameworks for settlements on different levels: International, European, National, Regional and Local. Identify ing development challenges and achieving aimed development level in line with development objectives; is a concept related to sustainable urban planning too.

Analy ses, planning and implementation of urban development presents the aim for better qualitative life through urbanization.

For achieving this aim should be clearly defined the role of urban planning, always, based on: innovative, economic, social and environmental perspectives for regulation, shaping and use of urban space. So, considering that urban planning is designed as system dealing with urbanization towards qualitative life in urban areas using rationally all resources for public interest and peoples welfare for community living there; it's understandable that people needs qualitative standards regarding shelter, work, transport, recreation and other for other local activities, so, city should be:

- Livable city

- Attractive city

- Safe city

- Sustainable city

"Community planning and design"..."Physically active residents"; to fulfill those above mentioned development concepts for city, should be considered some essential preconditions: professional human resources, case studies and good experiences, location and regulatory measures in correlation with economic, social and cultural development, environment protection and qualitative living standards too. 


\section{Development trends}

Urban planners, cannot operate effectively as isolated, because they are planning for community needs, so, based on some good international experiences worldwide with community in focus like "Community planning and design"... "Physically active residents"...is understandable the need for proactive community involvement in urban planning process.

This, because of better community welfare, environment protection and efficiency use of resources in urban area, but, this can be achieved only if there is strong partnership s between community (every day knowledge) and academy (expertise knowledge).

Why partnership academy-community is needed in urban planning process?

Its well-known from international practice-studies that nearly $20 \%$ from total contribution in urban planning belongs to academy, nearly $50 \%$ from total contribution in urban planning belongs to governing institutions while $30 \%$ from total contribution belongs community and private sector.

As it can be seen joint contribution of academy together with community comes nearly $70 \%$ and this contribution is based on integration of different respective knowledge's (every day-expertise) as strong tool for urban development, as it can be seen in the Fig. 1 below:

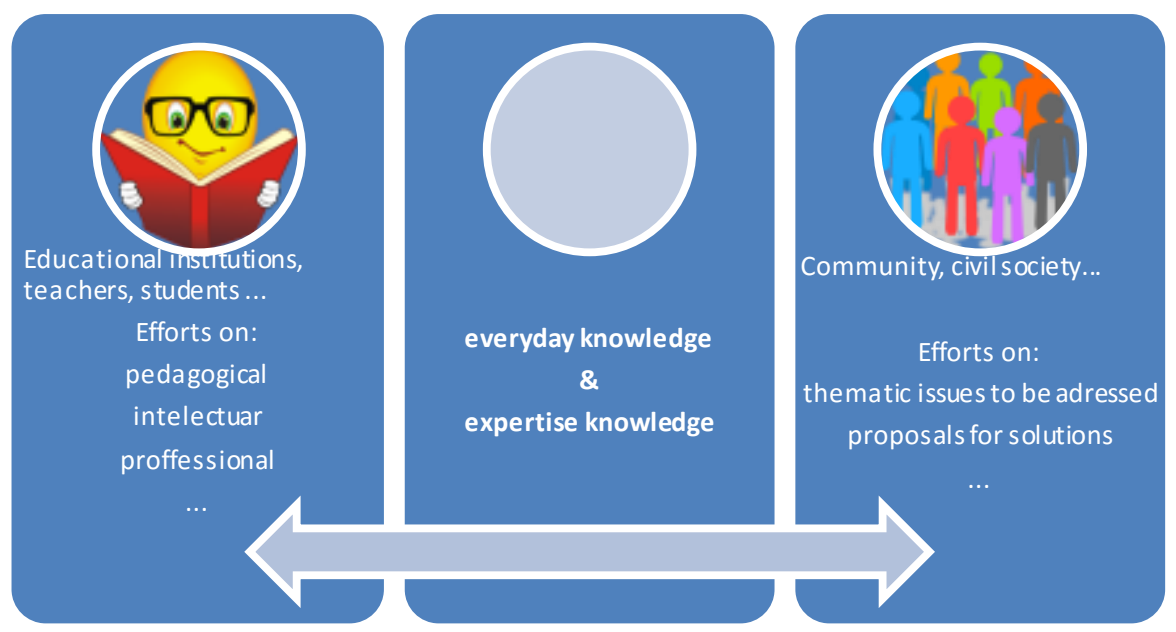

Fig1. Integrative process of partnership academy-community

\section{Research and ass essment of the topic}

Considering all preconditions for sustainable urban planning community based, all those should be elaborated. Based on survey with different citizens groups in Prishtina (September 2015), there are identified some of parameters to be considered in the process of sustainable urban planning:

- Build area to be proportional with human dimensions

- Rationality on peoples movement

- Human sense of people for urban space

- Interrelation of human activities in urban space

- Behavior of the people there

All those preconditions should be in agenda of partnership academy-community, in this way partners can have wider view for development planning based on their acting role in the process, because they are different actors in partnership for the same development vision.

Who is community in this partnership? The subject who offers some of the resources in promotion of sustainable urban development through: 
- Working space and equipment's

- Participating in budgeting partially

- Articulating every day knowledge

- $\quad$ Promoting their needs and requests

- Linking different actors

Who is academy in this partnership? The subject who offers professional competence through research and education in promotion of sustainable urban development through:

- $\quad$ Studies

- Research

- Consultation

- Trainings

This relationship between two partners in urban planning process and their contribution, is explained in the Fig. 2 as below, explaining framework of direct contribution of participants in the process.

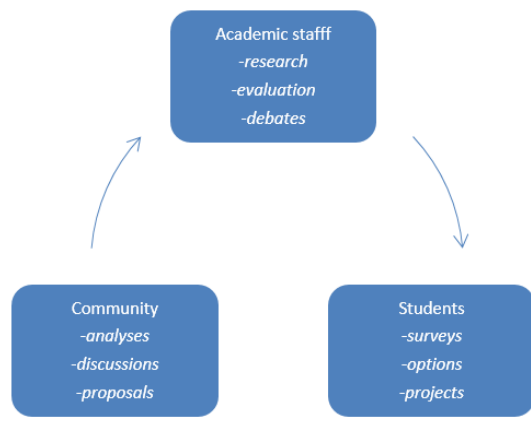

Fig2. Contribution of partners from partnership academy-community

How partnership can be established? Of course exploring and considering historical development of both sides, achievements and development aims. Establishing this partnership minds that should be considered specific and joint contribution of both sides as equal partners in the structure of partnership too. But, in this context, academy is expected to give more, as explained in Fig. 3. This contribution can be structured in three main pillars: study curriculum, academic staff and students; all of them linked in the circle.

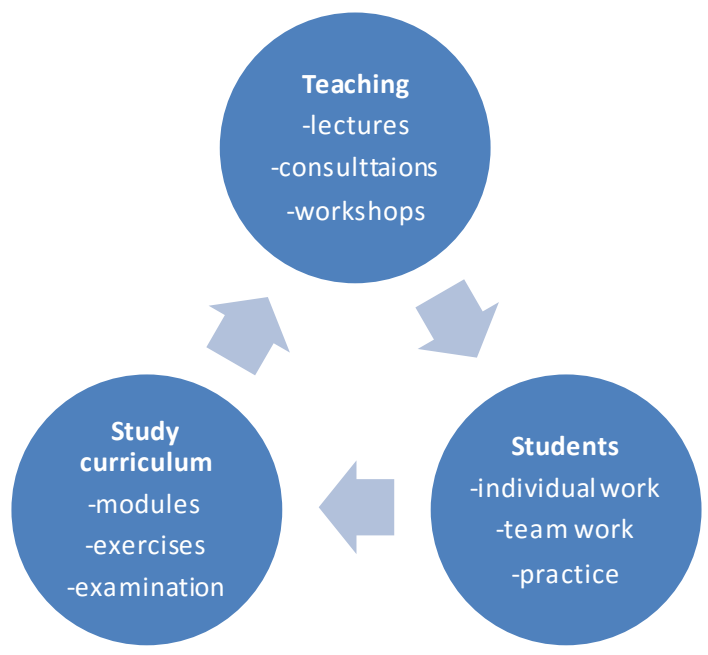

Fig3. Three pillars of academy 
How partnership can be developed successfully? Of course if it is based on: legitimacy of development process, flexibility on involvement, reciprocal reliability through activities, inclusiveness and proactive role of partners, especially oriented towards treatment of "non- heard voices" and marginalized structures of the society. This can be articulated only through the process where projects are knowledge based and knowledge has a circle flow as presented in Fig.4, through different project phases from analyses to planning towards implementation.

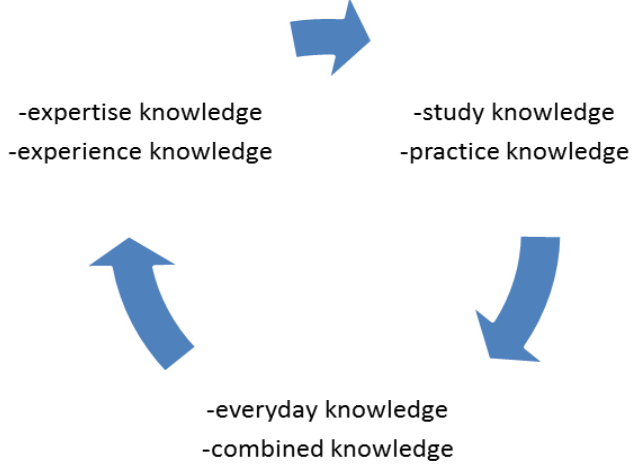

Fig4. Circle flow of knowledge, from partnership relations

Like other partnerships, partnership academy-community, is a concept values based:

- Is specific because of nature of partners

- $\quad$ Based on memorandum of good understanding

- Helpful for sharing knowledge and use of it

- Establishes network, not only between partners but wider

- Is with influence on changes

Considering that sustainable urban planning can be considered as development process oriented to:

- Quality of life

- Equity between people

- Ethical dimension

- Rationality and efficiency

The framework of sustainable urban development can be seen in Fig.5, where key elements of this framework can be considered as integrative elements for partnership academy-community

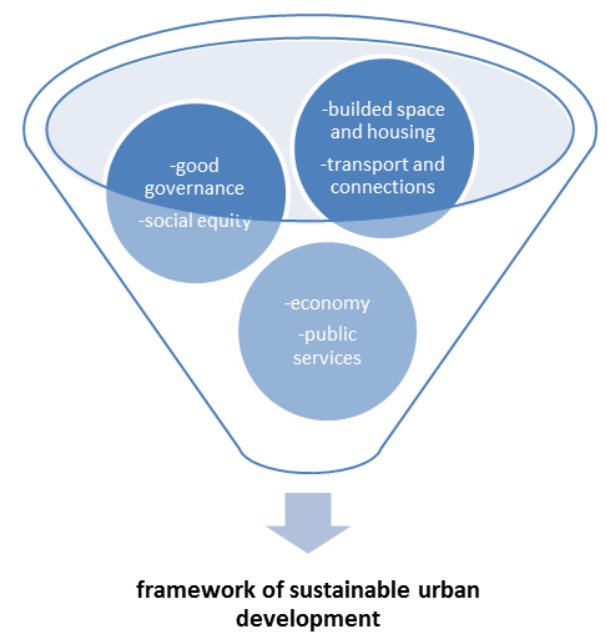

Fig. 5. Key elements of framework for sustainable urban development 
Always partnerships should be based on reciprocity, integrative approach, and interrelated communication towards expected results-outputs from the process. It's understandable that cooperation between partners, starts from problem identification and challenges... to planning and implementation; carefully so that partners should feel their part of ownership in this process, so, they can be helpful for benefits of society in general through sustainable urban planning. The community proactive role in partnership brings to community empowerment in the process as presented in Fig.6, which presents also integrative approach in urban planning.

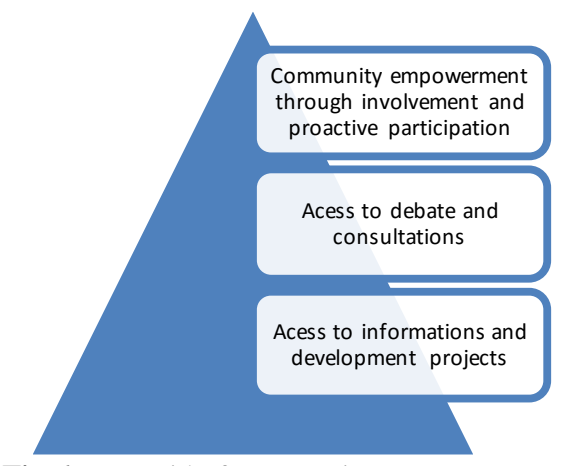

Fig.6. Py ramid of community empowerment

\section{Conclusions}

The road-map for development of partnership academy-community, in the process of sustainable urban planning is complex and with challenges, even though main interest of both sides is positive change based on scientific approach to bring contemporary urban developments in urban area with direct impacts on daily life of its citizens. Those relationships can be developed based on well-known level from professional literature as "The Golden relationships", securing sustainability of and improvement of partnership because of:

- Academy, as organization community based

- Community basic approach on development projects

- Urban sustainable development, based on clear objectives

- Making integration happened through economic, social and environmental dimension

This, in context that urban units are under rapid growth nowadays, are becoming bigger and bigger, but, people there are remaining smaller and smaller!

\section{References}

1. Charles Montgomery, "Transforming our lives through urban design”, (2013)

2. Setha M. Low, Neil Smith, "The politics of public space", (2006)

3. Peter John, "Analyzing public policy", (2013)

4. Binak Beqaj, "Zhvillimi urban, planifikimi dhe dizajni”, (2015)

5. Jan Gehl, "Life between buildings using public space", (2011)

6. Jan Gehl, "Cities for people", (2010)

7. Ministry for the Environment, Wellington, "The Value of Urban Design. The Economic, Environmental and Social Benefits of Urban Design". (2005)

8. Baltic University Urban Forum, "Built Environment and Revitalization", (2006)

9. John Chang, "The problematization of urban spravl in the United States", (2006)

10. EU Commission, "Making our Cities Attractive and Sustainable", (2010)

11. World Bank, "Measuring Growth and Change in Metropolitan Form", (2012)

12. World Bank, "Vleresimi i sektorit urban ne Shqiperi", (2007) 